\title{
SeParating Politics from Policy in FCC MERGER REVIEWS: A BASIC Legal PRIMER Of THE "PubliC
INTEREST" STANDARD
}

Thomas M. Koutsky, Esq. ${ }^{\dagger}$ and Lawrence J. Spiwak, Esq. ${ }^{\ddagger}$

\section{INTRODUCTION}

The purpose of this article is to present a brief primer of the "public interest" standard that the Federal Communications Commission ("FCC" or "Commission") uses in reviewing mergers pursuant to the Communications Act. As outlined more fully below, precedent dictates that the FCC has independent (and indeed broader) authority to review communications industry mergers separate from the authority bestowed upon the Department of Justice ("DOJ") or Federal Trade Commission ("FTC"), and that this public interest review provides a useful and unique purpose. To the extent the FCC finds that the proposed transaction harms the public interest in some way, the Commission is well within its public interest authority to issue narrowly-tailored conditions to its approval of the merger.

However, precedent also dictates that the FCC's "public interest" authority is not unfettered. The public interest test requires an analysis of economic and competitive considerations, and the courts have sometimes rebuked the FCC \footnotetext{
Studies.

Resident Scholar, Phoenix Center for Advanced Legal \& Economic Public Policy

$\ddagger$ President, Phoenix Center for Advanced Legal \& Economic Public Policy Studies. The views expressed in this paper are the authors' alone and do not represent the views of the Phoenix Center, its Adjunct Fellows, or any of its individual Editorial Advisory Board members.
} 
for not being consistent in this analysis. ${ }^{1}$ Absent a clear nexus to any mergerrelated harm, the FCC should not use case-specific merger adjudications to achieve indirectly via coerced "voluntary commitments" what it cannot do directly via rulemakings to accommodate particular political constituencies. Indeed, despite the FCC's mantra over the last decade or so that a merger must "enhance competition," the case law simply does not support such an expansion of power. To the contrary, the case law is clear that the FCC is bound by the same standard as antitrust enforcement agencies in that the agency cannot "subordinate the public interest to the interest of "equalizing competition among competitors."' Accordingly, if there are generic, unresolved policy issues - such as the increasingly contentious issue of network neutrality - then those issues are better handled in formal industry-wide inquiries or rulemakings where they can be effectively dealt with in a comprehensive manner. Important issues of public policy should not be decided in the course of closed negotiations over merger conditions in which only the regulator and the regulated entity participate. In contrast, Notices of Proposed Rulemakings ("NPRMs") or, at minimum, Notices of Inquiry ("NOIs"), have the benefit of offering the public a complete opportunity to comment on proposals and also result in consistent, industry-wide resolution of issues that apply across the board and, hopefully, stand the test of time.

\section{WHY DOES THE FCC HAVE THE AUTHORITY TO REVIEW INDUSTRY MERGERS?}

Every few years, and usually in the context of an important telecom or media merger, policymakers and regulated companies alike question whether the FCC's review of communications industry mergers is necessary. The DOJ and the FTC have authority to review mergers under antitrust laws, ${ }^{4}$ and courts supervise and review this process through Tunney Act proceedings. ${ }^{5}$ While de-

See discussion infra Part IV.

2 In re NYNEX Corporation, Transferor, and Bell Atlantic Corporation, Transferee, for Consent to Transfer Control of NYNEX Corporation and Its Subsidiaries, Memorandum Opinion and Order, 32 F.C.C.R. 19,985, 2 (Aug. 14, 1997) (emphasis added) [hereinafter Bell Atlantic/NYNEX Order].

3 Hawaiian Tel. Co. v. FCC, 498 F.2d 771, 776 (D.C. Cir. 1974). See discussion infra Part IV.

4 Section 7 of the Clayton Act proscribes any merger that may "substantially ... lessen competition." 15 U.S.C. $\S 18$ (2006). Mergers of a particular size are not allowed to proceed until either the DOJ or FTC reviews the proposed transaction for adherence to pre-merger notification and reporting processes. Hart-Scott-Rodino Antitrust Improvements Act of 1976, 15 U.S.C. $\S 18(\mathrm{a})(2006)$.

515 U.S.C. $\$ 16$ (2006). For a good explanation of the Tunney Act process, see Law- 
bates continue about how vigorously various presidential administrations approach the antitrust process, ${ }^{6}$ there is very little serious debate over whether the antitrust Hart-Scott-Rodino merger pre-approval process is an important (and sometimes dramatic) check on market power. Yet, given the FCC's recent proclivity to require merged entities to accept voluminous "voluntary" merger commitments after months of protracted delay, many scholars legitimately contend that the FCC has no place in reviewing telephone, cable, broadcast, and wireless industry mergers in addition to DOJ or FTC review. ${ }^{7}$ As such, it is appropriate to explore precisely what $\mathrm{FCC}$ review adds to this process.

First, FCC has the authority - and the obligation - to review industry mergers because it is the current law. For example, under Section 214(a), "No carrier ... shall acquire or operate any line" without first obtaining from the Commission a certificate of public convenience and necessity. ${ }^{8}$ Similarly, pursuant to Section $310(\mathrm{~d})$, the Commission must find that any transfer of a permit or license serves the public interest, convenience, and necessity. ${ }^{9}$ Moreover, the Communications Act gives the FCC the authority to impose conditions on transactions so long as those conditions are consistent with applicable law. For example, Section 214(c) of the Communications Act states that the Commission "may attach to the issuance of [a 214] certificate such terms and conditions as in its judgment the public convenience and necessity may require." Section 303(r) provides that "[e]xcept as otherwise provided in this Act, the Commission ... shall . . . prescribe such . . conditions, not inconsistent with

rence M. Frankel, Rethinking the Tunney Act: A Model for Judicial Review of Antitrust Consent Decrees, 75 ANTITRUST L.J. 549, 551 (2008).

6 See, e.g., David A. Balto, Antitrust Enforcement in the Clinton Administration, 9 CORNELL J.L. \& PUB. POL'Y 61, 64 (1999).

7 See, e.g., Randolph J. May, A Modest Plea for FCC Modesty Regarding the Public Interest Standard, 60 AdMIN. L. REv. 895, 904-05 (2008); Randolph J. May, Reform the Process, NaT'L L. J. May 30, 2005, at 27; PeTer Huber, Law and Disorder IN CYBerSPaCE: ABolish the FCC and Let Common Law Rule the Telecosm 88-90 (1997); Philip J. Weiser, Reexamining the Legacy of Dual Regulation: Reforming Dual Merger Review by the DOJ and the FCC, 61 FED. COMM. L.J. 167, 197-98 (2008); Bradley Dugan, The FCC's New Formula for Mergers, 29 LOY. L.A. ENT. L. REV. 435, 461-65 (2009) (describing the contradictory approach of the FCC's approval of the Sirius-XM merger and the denial of the EchoStar-DirecTV merger); Daniel F. Spulber \& Christopher S. Yoo, Rethinking Broadband Internet Access, 22 HARV. J.L. \& TECH. 1, 15-16, 59 (addressing the inconsistency of the FCC's merger decisions regarding cable modem operators merging in the late 1990s); but $c f$. David A. Curran, Rethinking Federal Review of Telecommunications Mergers, 28 OHIO N. U. L. REV. 747, 753-57 (2002).

$8 \quad 47$ U.S.C. $\S 214(\mathrm{a})(2006)$.

$9 \quad$ Id. $\$ 310(\mathrm{~d})$.

$10 \quad$ Id. $\S 214(\mathrm{c})$. 
law, as may be necessary to carry out the provisions of this Act."11

Given the complexity of the communications industry, Congress understood that while a primary examination of competitive issues by antitrust enforcement agencies is important, the FCC also needs to consider a number of other factors that are not part of the typical Hart-Scott-Rodino antitrust merger review process. ${ }^{12}$ Several of those factors are discussed in Section III below. ${ }^{13}$ While the antitrust agencies (via the Hart-Scott-Rodino process) are in an excellent position to address whether a particular merger would "substantially lessen competition," ${ }^{14}$ the Clayton Act standard does not account for how the continuing presence of other residual "public interest" obligations required by law-most notably universal service requirements, ${ }^{15}$ issues of public health and safety, ${ }^{16}$ foreign ownership restrictions, ${ }^{17}$ etc.-affects firms' conduct and industry structure. ${ }^{18}$ Moreover, this dual-review process is not unique to the communications industry, as Congress also established a dual-review process for other complex industries, such as electricity and banking, where a similar dynamic analysis of non-traditional factors must be taken into account. ${ }^{19}$

In addition, the antitrust enforcement agencies simply may not have the industry expertise to understand all of the complexities and nuances of the tele-

$11 \quad$ Id. at $\S 303(\mathrm{r})$ (emphasis added).

12 See H.R. REP. No. 104-458, at 201 (1996) (Conf. Rep.) (explaining that even though the Act removes the FCC's ability to insulate telecommunications companies from DOJ antitrust review, it does not remove its ability to review for licensing purposes).

13 See discussion infra Part III.

14 15 U.S.C. $\S 18(2006)$.

15 See 47 U.S.C. $\$ 254$ (2006).

16 See, e.g., Implementing a Nationwide, Broadband, Interoperable Public Safety Network in the $700 \mathrm{MHz}$ Band, PS Docket No. 06-229, Second Report and Order, 22 F.C.C.R. 15,289 (2007).

17 See 47 U.S.C. $\$ 310$ (b)-(d) (2006). For a general critique of the FCC's handling of foreign investment in U.S. carriers, see Lawrence Spiwak, From International Competitive Carrier to the WTO: A Survey of the FCC's International Telecommunications Policy Initiatives 1985-1998, 51 FED. COMM. L.J. 111 (1998); addendum 51 FED. COMM. L.J. 519 (1999).

18 See United States v. FCC, 652 F.2d 72, 88 (D.C. Cir. 1980) ("[R]esolution of the sometimes-conflicting public interest considerations 'is a complex task which requires extensive facilities, expert judgment and considerable knowledge of the *** industry. Congress left that task to the Commission ...."') (quoting McLean Trucking Co. v. United States, 321 U.S. 67, 87 (1944)).

19 See generally Lawrence J. Spiwak, Expanding the FERC's Jurisdiction to Review Utility Mergers, 15 ENERGY L.J. 385 (1993) (explaining the process used by the Federal Energy Regulatory Commission to review utility mergers under the Federal Power Act and now-repealed Public Utility Holding Company Act); J. Robert Kramer II, Antitrust Review in Banking and Defense, 11 GEO. MASON L. REV. 111, 115-17 (2002) (explaining how bank mergers are regulated by the Federal Reserve Board, the Office of the Comptroller of the Currency, the Federal Deposit Insurance Commission, and the DOJ). 
com business. ${ }^{20}$ In light of rapid technological change, using the DOJ/FTC Horizontal Merger Guidelines ("Merger Guidelines") ${ }^{21}$ as the only guidepost for reviewing industry transactions could force the merger review process to rely solely upon a rigid, static view of industry structure..$^{22}$ Moreover, the Merger Guidelines are simply not designed to account for the myriad of FCC rulemakings and adjudications that occur literally everyday and which often affect any static competitive analysis. For both of these reasons, it is not uncommon for the FCC to detail staff and lend its expertise to the DOJ or FTC to assist in those agencies' reviews of communications industry mergers under the Clayton Act. ${ }^{23}$

Courts have long recognized the FCC's unique expertise in dealing with the sometimes Byzantine aspects of communications industries. Indeed, in 2005, the Supreme Court noted that because the FCC must make difficult decisions regarding issues that "involve a 'subject matter [that] is technical, complex, and dynamic," the "Commission is in a far better position to address these questions than [a court of general jurisdiction]." 24

Recent communications industry transactions present a particularly compelling case for independent FCC review because many of the recent deals flow directly from FCC policy decisions that favor facilities-based entry or "intermodal competition" over other alternatives. ${ }^{25}$ Indeed, as technology continues to facilitate convergence among competing distribution platforms, the logical

20 See Jonathan E. Nuechterlein \& Philip J. Weiser, First Principles for an Effective Rewrite of the Telecommunications Act of 1996 (AEI-Brookings Joint Ctr. for Regulatory Studies, Working Paper No. 05-03, 2005), available at http://papers.ssrn.com/sol3/papers.cfm?abstract_id=707124 (noting that "the FCC, despite its well-known flaws, will remain better suited than antitrust courts for [the role of] . . . superintending the efficient development of competition throughout the industry").

21 U.S. DeP'T OF JuSTICE \& Fed. TRAdE COMM'N, HorizonTAl MERGER Guidelines (1997), available at http://www.usdoj.gov/atr/public/guidelines/hmg.pdf. In 1996, the DOJ and FTC issued a joint commentary on the application of the Guidelines, which includes discussions of how the agencies have applied and interpreted the Guidelines over the last decade. U.S. DEP'T OF JuSTICE \& FED. TRADE COMM'N, COMMENTARY ON THE HoRIzONTAL MERGER GUIDELINES (Mar. 2006), available at http:/www.ftc.gov/os/2006/03/CommentaryontheHorizontalMergerGuidelinesMarch2006.p df.

22 Lawrence J. Spiwak, What Hath Congress Wrought? Reorienting Economic Analysis of Telecommunications Markets After The 1996 Act, ANTITRUST (Spring 1997) at 32.

23 The Effects of Consolidation on the State of Competition in the Telecommunications Industry: Hearing Before the H. Comm. on the Judiciary, 105th Cong. 21 (1998) (statement of Joel I. Klein, Assistant Attomey General, Antitrust Division, U.S. Department of Justice).

24 Nat'l Cable \& Telecomm. Ass'n v. Brand X Internet Servs., 545 U.S. 967, 1002-03 (2005) (internal citation omitted).

25 See John Blevins, A Fragile Foundation-The Role of "Intermodal" and "FacilitiesBased" Competition in Communications Policy, 60 ALA. L. REV. 241, 250-54 (2009). 
outcome of a policy focus on "inter-modal competition" has been a phase of "intra-modal mergers" among similarly situated companies seeking to maximize economies of scale and scope. ${ }^{26}$ Given the direct interrelationship between these mergers and regulatory policy, the FCC stands in an important position to determine whether these proposed intra-modal transactions will advance Congress' long-standing policy mandate that "all the people of the United States [shall have access to] a rapid, efficient, Nation-wide, and worldwide . . . communication service with adequate facilities at reasonable charges ...."27

The industry has been down this path before. When the FCC auctioned off the PCS spectrum in the mid-1990s, it essentially guessed that five wireless carriers (the existing two cellular carriers plus the A, B, and C PCS spectrum blocks) was the appropriate number of firms for the market and also supposed that regional-as opposed to national-geographic licensing would be appropriate. ${ }^{28}$ Prior research has demonstrated that because significant fixed and sunk costs are inherent in the telecom industry, the number of firms will tend to reach a relatively concentrated equilibrium. ${ }^{29}$ But the FCC could not have known in the early 1990s whether or not five wireless carriers was ideal, and it erred on the side of caution by auctioning off several licenses in distinct geo-

26 These mergers include continued consolidation among cable multiple system operators, such as the 2006 acquisition of the Adelphia cable systems by Comcast and Time Warner Cable. See In re Applications for Consent to the Assignment and/or Transfer of Control of Licenses; Adelphia Communications Corporation, (and subsidiaries, debtors-inpossession), Assignors, to Time Warner Cable Inc. (subsidiaries), Assignees; Adelphia Communications Corporation, (and subsidiaries, debtors-in-possession), Assignors and Transferors, to Comcast Corporation (subsidiaries), Assignees and Transferees; Comcast Corporation, Transferor, to Time Warner Inc., Transferee; Time Warner Inc., Transferor, to Comcast Corporation, Transferee, Memorandum Opinion and Order, 21 F.C.C.R. 8203, ๆๆ 1-5 (July 13, 2006) [hereinafter Adelphia Order].

2747 U.S.C. $\$ 151$ (2006).

28 J. Gregory Sidak et al., A General Framework for Competitive Analysis in Wireless Telecommunications, 50 HASTINGS L.J. 1639, 1646 n. 16 (1999); see Kathleen Q. Abernathy, My View from the Doorstep of FCC Change, 54 FED. COMM. L.J. 199, 218 (2002).

29 See, e.g., J.B. Duvall \& G.S. Ford, Changing Industry Structure: The Economics of Entry and Price Competition, 7 TeleCOMM. \& SPACE J. 11, 17-21 (2001); T. Randolph Beard, George S. Ford \& Lawrence J. Spiwak, Why ADCo? Why Now? An Economic Exploration into the Future of Industry Structure for the "Last Mile" in Local Telecommunications Markets, 54 FED. COM. L. J. 421, 423-26 (2002); George S. Ford, Thomas M. Koutsky \& Lawrence J. Spiwak, Competition After Unbundling: Entry, Industry Structure and Convergence, 59 FED. COMM. L.J. 331, 332-33 (2007) (presenting an economic model demonstrating that "fixed and sunk costs inherent to the construction and commercial operation of communications networks" will keep the "equilibrium level of concentration of ... firms in local communications markets ... relatively high"). 
graphic areas. ${ }^{30}$ If the natural equilibrium structure favored fewer and larger national players, then mergers should have been expected as a natural consequence of this initial policy choice in selecting a "starting point."31 Accordingly, the subsequent wave of wireless mergers was an entirely logical outcome and reaction (or "sorting") by the market in response to a deliberate public policy choice. Antitrust agencies and the FCC may view such developments in a different light: to an antitrust agency, rapid consolidation may signal an imminent competition problem, while to the FCC, such rapid consolidation is the expected consequence of a conscious public policy choice. In this environment, traditional tools of antitrust analysis might not present a complete picture of the emerging competitive dynamic. ${ }^{32}$

The same can be said for competition issues relating to vertical conduct and acquisitions. The trend in antitrust law has been not to review "vertical" mergers closely, based on the arguments of scholars that such transactions often promote economic efficiency and only rarely have adverse competitive effects. ${ }^{33}$ In contrast, public policy has traditionally treaded more carefully re-

30 See, e.g., In re Geographic Partitioning and Spectrum Disaggregation by Commercial Mobile Radio Services Licensees; Implementation of Section 257 of the Communications Act - Elimination of Market Entry Barriers, Report and Order and Further Notice of Proposed Rulemaking, 11 F.C.C.R. 21,831, १ी 1-2 (Dec. 13, 1996).

31 A similar result occurred in radio broadcasting, where FCC rules, until gradually loosened beginning in the early 1970 s, created maximum fragmentation in the industry by nearly forbidding multi-station owners. See Robert B. Ekelund, Jr., George S. Ford \& Thomas Koutsky, Market Power in Radio Markets: An Empirical Analysis of Local and National Concentration, 43 J. L. \& ECON. 157, 160-64 (2000).

32 Many courts have found this to be true. See, e.g., United States v. Baker Hughes Inc., 908 F.2d 981, 986 (D.C. Cir. 1990) (Thomas, J.) (explaining that market share statistics can be "easily skewed" and sometimes "“volatile and shifting") (internal citation omitted); $\mathbf{S}$. Pac. Commc'ns Co. v. AT\&T, 740 F.2d 980, 1000 (D.C. Cir. 1984), cert. denied, 470 U.S. 1005 (1985) ("A predominant market share may merely be the result of regulation, and regulatory control may preclude the exercise of monopoly power .... [I]n such cases market share should be at most a point of departure in determining whether monopoly power exists."); Metro Mobile CTS, Inc. v. New Vector Commc'ns Inc., 892 F.2d 62, 63 (9th Cir. 1989) ("Reliance on statistical market share in cases involving regulated industries is at best a tricky enterprise and is downright folly where ... the predominant market share is the result of regulation."). See also Duncan Cameron \& Mark Glick, Market Share and Market Power in Merger and Monopolization Cases, 17 Managerial \& DeCision Econ. 193, 193 (1996) (asserting that "legal precedent requiring the courts to draw inferences about market power based primarily or exclusively on market shares and/or market concentration can often be misleading .... [T] he only alternative to such judge-made bright-line rules is to utilize modern economic tools to undertake more extensive competitive analyses").

33 See, e.g., Daniel F. Spulber \& Christopher S. Yoo, Mandating Access to Telecom and the Internet: The Hidden Side of Trinko, 106 CoLUM. L. REV 1822, 1834-43 (2007); Michael H. Riordan \& Steven C. Salop, Evaluating Vertical Mergers: A Post-Chicago Approach, 63 ANTITRUST L.J. 513, 513 (1995). 
garding vertical issues in the communications industry. ${ }^{34}$ These concerns have been notable in the context of access to video programming. Congress has passed laws that limit the ability of cable systems to restrict the distribution of video programming networks to rivals. ${ }^{35}$ Since many cable firms are vertically integrated with the most popular programming networks, concerns over whether cable mergers would impact the distribution of such programming networks play an important role in the FCC's merger review process. ${ }^{36}$

In reviewing cable industry mergers, the FCC makes a careful determination as to whether such programming distribution issues are better resolved through company-specific, merger-specific conditions, or whether existing program access laws, which apply to the industry generally, are sufficient. For exam-

34 In re Teleprompter Corporation; Theta Cable of California; Northwest Cablevision, Inc. d/b/a Teleprompter of Seattle; Teleprompter Southeast, Inc.; Teleprompter Southeast, Inc. $\mathrm{d} / \mathrm{b} / \mathrm{a}$ Teleprompter of Boca Raton; Teleprompter Southeast, Inc.; Teleprompter Corporation; Teleprompter Southeast, Inc.; Teleprompter Corporation; Teleprompter Southeast, Inc.; Teleprompter of San Bernardino, Inc.; Teleprompter Newburgh Cable TV Corp.; Teleprompter of Portsmouth, Inc.; Teleprompter of Mohawk Valley, Inc.; Teleprompter Island Cable TV Corp.; Focus Cable of Oakland, Inc.; El Paso Cablevision, Inc.; Mobile TV Cable Company, Inc.; Teleprompter of Fairmont, Inc. Teleprompter Corporation; Teleprompter Corporation d/b/a Teleprompter of Reno; Northeast Minnesota Cable TV, Inc.; Garden State Television Cable Corp.; Teleprompter Corporation d/b/a Teleprompter of Tucumcari; Teleprompter Corporation $\mathrm{d} / \mathrm{b} / \mathrm{a}$ Teleprompter of Ukiah; Teleprompter Corporation $\mathrm{d} / \mathrm{b} / \mathrm{a}$ Teleprompter of Santa Cruz; Teleprompter Corporation; Teleprompter Florida CATV Corp; Teleprompter Corporation; Applications for Transfer of Control in the Cable Television Relay Service, Memorandum Opinion and Order, 87 F.C.C.2d 531, ๆ 61 (July 30, 1981). In reviewing this cable industry merger, the Commission observed that:

[V]ertical integration has conflicting components, in terms of the incentives involved. While it may create a natural tendency for the systems involved to deal with affiliated enterprises, it is also the engine for the creation of new products and services to increase the value of the total package of services offered [to] the public. Given the conflicting incentives involved, we believe it would be inappropriate to conclude on any general basis that vertical integration is undesirable. Rather, what appears to be required is scrutiny of particular aspects of these vertical relationships for adverse consequences.

Id. (emphasis added) (citation omitted).

35 See 47 U.S.C. \& 548 (2006). In so doing, Congress "sought to promote entry into local distribution markets through interim limits on strategic vertical restraints between vertically-integrated cable operators and programmers." James W. Olson \& Lawrence J. Spiwak, Can Short-Term Limits on Strategic Vertical Restraints Improve Long-Term Cable Industry Market Performance?, 13 CARDOZO ARTS \& ENT. L.J. 283, 283 (1994).

36 According to the FCC's last Cable Competition Report, five of the top seven cable operators-Comcast, Time Warner, Cox, Cablevision, and Advance/Newhouse-hold ownership interests in satellite-delivered national programming networks. In total, 84 satellitedelivered national programming networks are affiliated with one or more of these cable operators. In re Annual Assessment of the Status of Competition in the Market for the Delivery of Video Programming, Thirteenth Annual Report, 24 F.C.C.R. 542, II 186 (Jan. 16, 2009). 
ple, when the FCC reviewed the acquisition of Adelphia Cable by Time Warner Cable and Comcast, it found that transaction would enable Comcast and Time Warner to raise the price of access to regional sports networks (like Comcast SportsNet) by imposing uniform price increases applicable to all multichannel video programming distributors, including their own systems. ${ }^{37}$ The Commission found that "[s]uch a strategy is likely to result in increased retail rates and fewer choices for consumers seeking competitive alternatives to Comcast and Time Warner." ${ }^{38}$ The FCC found that the acquisition, by increasing the regional "clustering" of cable networks in geographic areas, would enhance the cable firms' ability to force local sports teams and local sports viewers to deal with the local cable company with regard to showing such sports events on cable television. ${ }^{39}$ To resolve this merger-specific harm, the FCC approved the transaction subject to the imposition of narrowly-tailored mergerrelated arbitration conditions designed to alleviate the regional sports programming problem. ${ }^{40}$ But the FCC refrained from imposing broader obligations in response to arguments from competitors that they generally were having difficulty obtaining affiliated, national programming from Time Warner and Comcast. ${ }^{41}$ In that context, the FCC did not impose conditions because it reasoned that the existing program access rules were the appropriate forum to handle such disputes. ${ }^{42}$

In summary, the FCC has the legal obligation to review communications industry mergers. This dual review is not unique to the FCC and is also present in other industries like banking and energy..$^{43}$ The sheer breadth and complexity of the communications industry necessitates this dual review, because communications industry transactions reflect not only questions of static economic efficiency and market power, but they also reflect the shifting of regulatory policy and technological change. As the Supreme Court said in Brand $X$, "[n]othing in the Communications Act or the Administrative Procedure Act makes unlawful the Commission's use of its expert policy judgment to resolve these difficult questions." 44

See Adelphia Order, supra note 26, ๆๆ 123-24.

Id. 7295.

Id. ๆๆ $124-27,298$.

Id. ๆ $294-300$.

Id. โๆ 171-74.

Id. ๆ $173-74$.

See supra note 19 and accompanying text.

44 Nat'l Cable \& Telecomm. Ass'n v. Brand X Internet Servs., 545 U.S. 967, 1003 (2005). 


\section{THE “PUBLIC INTEREST" STANDARD REQUIRES A THOROUGH ECONOMIC ANALYSIS OF COMPETITIVE ISSUES}

Properly applied, the FCC's "public interest" merger review authority can navigate these waters and take into account the complex and unique characteristics of the communications industry. Precedent makes clear that in reviewing mergers pursuant to the public interest standard, the FCC must consider competitive effects and conduct a rigorous economic analysis. ${ }^{45}$ While one can dispute the FCC's application of economics in many prior proceedings, any argument that the "public interest" standard is devoid of meaning under current law (and, therefore, that the FCC should abdicate its core responsibilities and defer to the DOJ or FTC) simply is not supported by case law. ${ }^{46}$

While regulatory agency and antitrust merger review are different, they do share many of the same goals. As the D.C. Circuit first stated in 1968--and later reaffirmed in 1980 in United States v. FCC-the "basic goal of governmental regulation through administrative bodies and the goal of indirect governmental regulation in the form of antitrust law is the same-to achieve the most efficient allocation of resources possible." ${ }^{47}$ As a result, the D.C. Circuit "has insisted that the [administrative] agencies consider antitrust policy as an important part of their public interest calculus." ${ }^{\prime 48}$ In Town of Concord v. Boston Edison Co., now Supreme Court Justice Stephen Breyer wrote that the goals of regulation and antitrust laws are "low and economically efficient pric-

45 The universal requirement to consider competitive effects under the public interest standard stands in direct contrast to other, more politically-charged topics, like employee job concerns, which may only be considered when the statute provides specific language ordering the administrative agency to do so. See NAACP v. Fed. Power Comm'n, 425 U.S. 662 , 670 (1976). The Supreme Court noted that employee job concerns did not fall within the scope of the Federal Power Commission's "public interest" inquiry to ensure "just and reasonable rates," because "the use of the words 'public interest' in a regulatory statute is not a broad license to promote the general public welfare." Id. at 669-70.

46 See supra text accompanying notes 8-24. But see Randolph J. May, The Public Interest Standard: Is It Too Indeterminate to Be Constitutional?, 53 FED. COMM. L.J. 427, 453 (2001) "Congress must ask itself anew whether the public interest standard is indeed sufficiently 'concrete' to fulfill Congress' responsibility to set communications policies for the Information Age, or whether it is so vague that it can mean whatever three FCC Commissioners say it means on any given day."); RANDOLPH J. MAY ET AL., THE PROGRESS \& FREEdom Found., Digital age Communications ACT: Proposal of the Regulatory FrameWORK WORKING GROUP, RELEASE 1.021 (2005) (characterizing the "current model of regulation" as one "based on vague standards such as 'public interest' and 'just and reasonable"').

47 United States v. FCC, 652 F.2d 72, 88 (D.C. Cir. 1980) (quoting N. Natural Gas Co. v. FPC, 399 F.2d 953, 959 (D.C. Cir. 1968)).

48 Id. 
es, innovation, and efficient production methods." ${ }^{349}$ As such, assertions that no relationship exists between antitrust and economic regulation completely miss the point. ${ }^{50}$ Indeed, as Supreme Court Justice Felix Frankfurter stated nearly sixty years ago, "[ $\mathrm{t}]$ here can be no doubt that competition is a relevant factor in weighing the public interest."

While FCC review must include some degree of competitive analysis, the FCC is plainly permitted to come to different conclusions than a strict antitrust review conducted by the DOJ or FTC may determine. Indeed, the seminal case regarding the FCC's public interest authority-United States v. FCC-resulted from the DOJ disagreeing with, and challenging in court, the FCC's approval of an important transaction in the satellite industry in the $1970 \mathrm{~s}$, which the DOJ believed was anticompetitive. ${ }^{52}$ In that case, the D.C. Circuit ruled in favor of the FCC, stating that all the FCC must do, in the exercise of its responsibilities, is "make findings related to the pertinent antitrust policies, draw conclusions from the findings, and weigh these conclusions along with other important public interest considerations. ${ }^{.53}$ The United States v. FCC decision vividly shows that the FCC's authority, while it includes competition policies, is a separate and distinct duty from those of the antitrust enforcement agencies. In effectuating its duties, the FCC has a significantly different standard to guide its actions..$^{54}$

49 Town of Concord v. Boston Edison Co., 915 F.2d 17, 22 (1st Cir. 1990) (Breyer, C.J.), cert. denied, 499 U.S. 931 (1991).

so See, e.g., N. Natural Gas Co., 399 F.2d at 961 (stating that antitrust laws are a tool that a regulatory agency can use to bring "understandable content to the broad statutory concept of the "public interest." (internal citation omitted). See also United States v. AT\&T, 498 F. Supp. 353, 364 (D.D.C. 1980) (Green, J.) ("[I]t is not appropriate to distinguish between Communications Act standards and antitrust standards . . . . [because] both the FCC, in its enforcement of the Communications Act, and the courts, in their application of the antitrust laws, guard against unfair competition and attempt to protect the public interest."').

51 FCC v. RCA Commc'ns, Inc., 346 U.S. 86, 94 (1953); see also N. Natural Gas Co., 399 F.2d at 961 (noting that "competitive considerations are an important part of the "public interest" "standard).

52 United States v. FCC, 652 F.2d 72 (D.C. Cir. 1980).

53 Id. at 82 (emphasis added) (quoting N. Natural Gas Co., 399 F.2d at 961).

54 See In re Applications by American Broadcasting Cos., Inc. For assignment of Licenses of Stations WABC, WABC-FM, WABC-TV, New York, N.Y.: WLS-FM, WBKB, Chicago, Ill.; KGO, KGO-FM, KGO-TV, San Francisco, Calif.; KABC, KABC-FM, KABC-TV, Los Angeles, Calif. For Transfer of Control of Stations WLS, Chicago, Ill.; KQV and KQV-FM, Pittsburgh, Pa.; WXYZ, WXYZ-FM, WXYZ-TV, Detroit, Mich. For Assignments and Transfers of Ancillary Radio Facilities, Memorandum Opinion and Order, 7 F.C.C.2d 245, I 15 (Dec. 21, 1966) ("The Antitrust Division is charged with the enforcement of the antitrust laws ... while the Commission is charged with effectuating the policies of the Communications Act . ..."); see also In re Time Warner, Inc., 123 F.T.C. 171, 
The FCC's charge is no easy task, given the complexity and rapidlychanging nature of the communications industry. ${ }^{55}$ The Hart-Scott-Rodino Act merger review process focuses upon whether the merged firm would be able to sustain a "small but significant and nontransitory" increase in price over a very short time-span and will examine entry that is likely to occur within two years. ${ }^{56}$ This approach, by definition, largely focuses the attention of the antitrust enforcement agencies on the current competitive environment and not on the environment that is likely to emerge over the next five to ten years. The FCC's authority under the Communications Act is significantly broader because the FCC, like other administrative agencies, is "entrusted with the responsibility to determine when and to what extent the public interest would be served by competition in the industry." 57 Therefore, it is not unreasonable to

227 (1997) (Azcuenaga, Comm'r, dissenting). Azcuenaga explained that because the FCC already had rules in place prohibiting discriminatory prices and practices, there was "little justification" for the FTC to require Time Warner to "comply with communications law" and, therefore, to the extent that the proposed consent order offered "a standard different from that promulgated by Congress and the FCC, it arguably is inconsistent with the will of Congress"- as such, "It]here is much to be said for having the FTC confine itself to FTC matters, leaving FCC matters to the FCC." Id. (emphasis added).

55 See Turner Broad. Sys., Inc., v. FCC, 520 U.S. 180, 196 (1997) (noting that regulatory schemes concerning telecommunications have "special significance" because of the "inherent complexity and assessments about the likely interaction of industries undergoing rapid economic and technological change"); Denver Area Educ. Telecomms. Consortium, Inc., v. FCC, 518 U.S. 727, 742 (1996) ("[We are] aware . . of the changes taking place in the law, the technology, and the industrial structure, related to telecommunications, see, e.g., Telecommunications Act of 1996 . . . ."); Columbia Broad., Inc. v. Democratic Nat'l Comm., 412 U.S. 94, 102 (1973) ("The problems of regulation are rendered more difficult because the ... industry is dynamic in terms of technological change ...."); FCC v. Pottsville Broad. Co., 309 U.S. 134, 138 (1940) ("The Communications Act is not designed primarily as a new code for the adjustment of conflicting private rights through adjudication. Rather it expresses a desire on the part of Congress to maintain, through appropriate administrative control, a grip on the dynamic aspects of radio transmission.").

56 See Horizontal Merger Guidelines, 57 Fed. Reg. 41,554-55, 41,561-62 (Sept. 10, 1992)

57 United States v. FCC, 652 F.2d 72, 88 (D.C. Cir. 1980). See Northeast Utils. Serv. Co. v. FERC, 993 F.2d 937, 947-48 (1st Cir. 1993). The court noted that the public interest standard does not require the administrative agency in question, the Federal Energy Regulatory Commission, "to analyze proposed mergers under the same standards that the [DOJ] . . . must apply" because an administrative agency is not required to "serve as an enforcer of antitrust policy in conjunction" with the DOJ or FTC, and thus, while the agency "must include antitrust considerations in its public interest calculus ... it is not bound to use antitrust principles when they may be inconsistent with the [agency's] regulatory goals." Id. See also Nat'l Broad. Co. v. United States, 319 U.S. 190, 219 (1943) (explaining that Congress, through the Communications Act, "gave the Commission not niggardly but expansive powers."); In re Applications of Craig O. McCaw and Am. Tel. and Tel. Co., Memorandum Opinion and Order, 9 F.C.C.R. 5836, I 7 (Sept. 19 1994), aff'd sub nom. SBC Commc'ns v. FCC, 56 F.3d 1484 (D.C. Cir. 1995) (noting that the FCC's "jurisdiction under the Commu- 
expect the FCC to consider the ramifications of its policies over a longer period. Given this broader responsibility, it is incumbent upon the Commission, when reviewing industry transactions, to take a far more dynamic and flexible approach. $^{58}$

Still, commentators have argued that the FCC should simply abandon its merger review authority and defer all matters of competition analysis to the DOJ or FTC. ${ }^{59}$ But it is not entirely clear that the antitrust legal standards, particularly the "unfair competition" standard of Section 5 of the Federal Trade Commission Act, ${ }^{60}$ are also not subject to $a d$ hoc manipulation by enforcement authorities and regulatory excess. ${ }^{61}$ FCC merger orders under the "public interest" standard are subject to judicial review, just as courts review consent decrees entered into by the government and merging parties pursuant to the Tunney Act. ${ }^{62}$ As such, the argument that somehow the DOJ/FTC process is in fact inherently "better" or "more consistent" is entirely subjective.

\section{WITH GREAT POWER COMES GREAT RESPONSIBILITY}

Of course, while the FCC clearly has the obligation to examine competitive issues, a crucial question is whether there are any appropriate limits on the FCC's authority. Unfortunately, the FCC has in the past interpreted its mandate incorrectly, and did not limit its review to determining whether a merger is "in" or "consistent with" the public interest, ${ }^{63}$ but instead sought to utilize the

nications Act gives us much more flexibility and more precise enforcement tools that (sic) the typical court has").

58 Olson \& Spiwak, supra note 35, at 305-07. See generally Spiwak, supra note 23.

59 See, e.g., Weiser, supra note 7, at 198 ("A central challenge for regulatory agencies such as the FCC is to defer to the competition policy analysis of the DOJ as well as its choice of merger remedies. On balance, the agency's duplicative analysis has yielded few benefits while it has delayed merger approvals and imposed significant administrative costs.").

60 See 15 U.S.C. $\S 45(2006)$.

61 As former FTC Chairman Timothy Muris noted, the "unfair competition standard" in the wrong hands produced "a series of proposed rules relying upon vague theories of unfairness that often had no empirical basis, could be based entirely upon the Commissioners' personal values, and did not have to consider the ultimate costs to consumers of foregoing their ability to choose freely in the marketplace." Timothy J. Muris, Chairman, Fed. Trade Comm'n, Remarks at the Aspen Summit: Cyberspace and the American Dream (Aug. 19, 2003), available at http://www.ftc.gov/speeches/muris/030819aspen.htm\#N 49.

${ }_{62}$ See supra note 5 and accompanying text. But see Donald J. Russell \& Sherri Lynn Wolston, Dual Antitrust Review of the Telecommunications Mergers by the Department of Justice and the Federal Communications Commission, 11 GEo. MASON L. REV. 143, 154 (2002) (noting criticisms that FCC merger decisions are "effectively insulated from meaningful judicial review.").

63 See, e.g., Pacific Power \& Light Co. v. FPC, 111 F.2d 1014, 1016 (9th Cir. 1940). 
merger review process to otherwise "enhance the public interest." ${ }^{\text {" A }}$ As noted above, critics have legitimately seized upon this inconsistency and claimed that the FCC has abused its authority to impose narrowly-tailored merger conditions $^{65}$ and, therefore, cannot be trusted to uphold the basic maxim that competition policy-either by antitrust enforcement agencies or by administrative agencies - is designed to protect competition and not individual competitors. ${ }^{66}$ However, while the FCC has not always stuck to this fundamental precept, the law is clear that the FCC must exercise its public interest authority with analytical rigor and caution. ${ }^{67}$

The most important limitation on the FCC's public interest standard is the precept that the focus of the standard is upon the interests of the public, and not the interests of competitors who may seek to use the merger process to hamstring a competitor. For example, in the 1981 case of Hawailan Telephone $v$. $F C C{ }^{68}$ the D.C. Circuit remanded an FCC grant of Section 214 authority for service between the U.S. mainland and Hawaii because it found that the Commission had engaged in an ad hoc approach that improperly aimed at "equaliz-

The court found that it is "enough if the applicants show that the proposed merger is compatible with the public interest. The Commission, as a condition of its approval, may not impose a more burdensome requirement in the way of proof than that prescribed by law." Id. (emphasis added).

64 See, e.g., Bell Atlantic/NYNEX Order, supra note 2, I 2. In that decision, the FCC, rather than requiring applicants to demonstrate that their proposed merger was in the public interest for any number of possible reasons (like efficiency savings that would lead to lower rates), the FCC stated that

[i]n order to find that a merger is in the public interest, we must, for example, be convinced that it will enhance competition. A merger will be pro-competitive if the harms to competition ... a are outweighed by the benefits that enhance competition. If applicants cannot carry this burden, the applications must be denied."

Id. (emphasis added). Competition is certainly an important goal, but this singular focus on only that one public interest concern to the exclusion of others was, in our view, improper.

65 See sources cited supra note 7.

66 See, e.g., Brunswick Corp. v. Pueblo Bowl-O-Mat, 429 U.S. 477, 488 (1977) ("[A]ntitrust laws . . . were enacted for "the protection of competition not competitors." (quoting Brown Shoe v. United States, 370 U.S. 294, 320 (1962))).

67 Cf. Cincinnati Bell Tel. Co. v. FCC, 69 F.3d 752, 760 (6th Cir. 1995) (reversing FCC decision because the order contained no "expert economic data or [analogies] to related industries in which the claimed anticompetitive behavior has taken place" but instead justified its conclusions as "simply 'common sense"); FCC v. RCA Commc'ns, Inc., 346 U.S. 86, 93-95 (Frankfurter, J.) (noting that the FCC's economic analysis may not primarily rely on a "reading of national policy" because agency's actions were simply "too loose and too much calculated to mislead in the exercise of the discretion entrusted to it.").

68 Hawaiian Tel. Co. v. FCC, 498 F.2d 771 (D.C. Cir. 1974). The "public interest" standard in the Communications Act is applied in many contexts, such as the granting of licenses, so court decisions on those topics, like Hawaiian Telephone, provide important insight on the limitations of the FCC authority in this area. 
ing competition among competitors." ${ }^{69}$ The D.C. Circuit stated that FCC's public interest analysis must be more than an inquiry into "whether the balance of equities and opportunities among competing carriers suggests a change." The court found that it was "[a]ll too embarrassingly apparent that the Commission has been thinking about competition, not in terms primarily as to its benefit to the public, but specifically with the objective of equalizing competition among competitors." $" 11$

Subsequent decisions reiterate the importance that consumer welfare analysis plays in the FCC's public interest standard. In 1995, various parties challenged the Commission's approval of the acquisition of McCaw Cellular licenses by AT\&T by arguing that the FCC should have imposed the antitrust Modified Final Judgment ("MFJ") restrictions applicable to the Regional Bell Operating Companies ("RBOCs") on the merged firm. ${ }^{72}$ Citing Hawaiian Telephone, the D.C. Circuit rejected the merger opponents' arguments and found that the application of the MFJ restrictions to the merged entity would "serve the interests only of the RBOCs rather than those of the public."73 The court stated that when the Commission considers whether a proposed merger serves the public interest, the "Commission is not at liberty . . . to subordinate the public interest to the interest of 'equalizing competition among competitors."

The FCC's merger review authority is also indirectly limited by statute, in that merger conditions cannot be used to avoid statutory mandates. ${ }^{75}$ In 2001 , the D.C. Circuit overturned the FCC's conditional approval of SBC's acquisi-

69 Id. at $774-76$

$70 \quad I d$. at 776 .

$71 \quad I d$. at $775-76$.

72 SBC Commc'ns Inc. v. FCC, 56 F.3d 1484, 1490 (D.C. Cir. 1995).

73 Id. at 1491.

74 Id. (quoting Hawaiian Tel. Co. v. FCC, 498 F.2d 771, 776 (D.C. Cir. 1974) (emphasis added); see also W. Union Tel. Co. v. FCC, 665 F.2d 1112, 1122 (D.C. Cir. 1981) ("[E]qualization of competition is not itself a sufficient basis for Commission action."). One of the counter-arguments to this position is the often misguided notion that the naked "protection of competitors" is the analytical equivalent to attempting to promote tangible new entry into a market currently dominated by a monopoly incumbent. It is not. As the FCC's former chief economist argued, it is "important that the playing field should be leveled upwards, not downwards" because "rules that forbid a firm from exploiting efficiencies just because its rivals cannot do likewise" harm, rather than improve, consumer welfare. Joseph Farrell, Creating Local Competition, 49 FED. COMM. L.J. 201, 212 (1996). In highly concentrated industries, the focus of policy should be on regulation that promotes competitive entry, rather than regulation that protects competition. The latter will often turn into the mere protection of the private interests of competitors.

75 Section 303(r) of the Communications Act provides that "except as otherwise provided in this chapter, the Commission . . . shall prescribe such . . conditions, not inconsistent with law, as may be necessary to carry out the provisions of this Act." 47 U.S.C. $\S$ 303(r) (2006) (emphasis added). 
tion of Ameritech, holding that the FCC unreasonably used its merger review authority to attempt to allow the merged entity to avoid section 251 obligations by means of a merger condition. ${ }^{76}$ This SBC/Ameritech merger condition permitted the merged firm to provide advanced services through a separate subsidiary that would not be subject to the unbundling and resale provisions of section 251 of the Act. ${ }^{77}$ Competitors challenged that decision, arguing that the FCC's condition was "simply a device to accomplish indirectly what the statute clearly forbids ..."78 and constituted an unreasonable exercise of the FCC's merger review authority. ${ }^{79}$ The D.C. Circuit agreed and called the FCC's action an attempt to "sideslip $\S 251$ (c)'s requirements . . .." Therefore, while the FCC has statutory authority to review and condition mergers, it does not have the authority to use merger conditions to circumvent the statutes the agency is charged with administering.

Finally, legal scholars have expressed concern that the authority to review mergers is a powerful tool that can easily be misapplied. ${ }^{81}$ With regard to important industry transactions, this "hold up" power borders on granting the agency absolute power for which there is no check or balance. If agencies approach this task without self-limiting their use of this authority, then the potential to use the process to aggrandize authority and abuse it will be strong. As Judge Frank Easterbrook observed well over twenty five years ago:

Often an agency with the power to deny an application (say, a request to commence service) or to delay the grant of the application will grant approval only if the regulated firm agrees to conditions. The agency may use this power to obtain adherence to rules that it could not require by invoking statutory authority. The conditioning power is limited, of course, by private responses to the ultimatums - firms will not agree to conditions more onerous than the losses they would suffer from the agency's pursuit of the options expressly granted by the statute. The firm will accept the conditions only when they make both it and the agency (representing the public or some other constituency) better off. Still, though, the agency's options often are potent, and the grant

76 Ass'n of Commc'ns Enters. v. FCC, 235 F.3d 662, 663, 666-68 (D.C. Cir. 2001).

77 See In re Applications of Ameritech Corp., Transferor, and SBC Communications, Inc., Transferee, For Consent to Transfer Control of Corporations Holding Commission Licenses and Lines Pursuant to Sections 214 and 310(d) of the Communications Act and Parts 5, 22, 24, 25, 63, 90, 95, and 101 of the Commission's Rules, Memorandum Opinion and Order, 14 F.C.C.R. 14,712, १1 444-45 (Oct. 6, 1999). Commissioner Harold Furchtgott-Roth dissented from this part of the FCC's order. In a separate statement that foreshadowed the D.C. Circuit's future ruling, Commissioner Furchtgott-Roth stated that the conditions adopted were "inconsistent with specific sections of the Communications Act." Id. (separate statement of Commissioner Furchtgott-Roth).

78 Ass'n of Commc'ns Enters., 235 F.3d at 665.

$79 \quad$ Id. at 668 .

80 Id. at 666.

81 See, e.g., Frank Easterbrook, The Supreme Court, 1983 Term-Foreword: The Court and the Economic System, 98 HARV. L. REV. 4, 39 (1984). 
of an application on condition may greatly increase the span of the agency's control. ${ }^{82}$

Thus, FCC Commissioners should exercise restraint on their collective or individual efforts to use the FCC's merger authority to alter the industry through "voluntary" merger commitments that would otherwise be unobtainable through the "normal channels."

Accordingly, while the FCC is well within its authority to issue narrowlytailored conditions as appropriate to remedy a merger-related harm, viewing industry mergers as opportunities to promote or jump-start an affirmative public policy agenda via so-called "voluntary" merger commitments-particularly if policymakers are frustrated by an inability to achieve a political consensus on nationwide rules of general applicability-is a troubling extension of regulatory authority by the FCC. While it may be appealing for policymakers to attempt to advance a policy agenda through merger conditions, using the leverage of the merger review process to force a particular outcome down the throats of one particular firm in the industry ultimately may constitute a violation of the public trust. Instead of acting consistent with the public interest, the FCC would be advancing a public policy agenda for which it otherwise may not have the legal authority or political support.

Moreover, coercing merging parties to accept "voluntary" commitments may fail to solve industry-wide problems with industry-wide solutions. ${ }^{83}$ For example, AT\&T and Verizon respectively agreed to conduct their businesses in accordance with the Commission's Broadband Internet Access Policy State$m e n t^{84}$ as part of voluntary merger commitments made in relation to the SBC-

82 Id. (emphasis added).

83 For example, the FCC was effectively enjoined by the Eighth Circuit from enforcing the TELRIC pricing rules standard for unbundled network elements with incumbent LECs and the state commissions. Iowa Utils. Bd. v. FCC, 120 F.3d 753, 794-96 (8th Cir. 1997), aff'd in part, rev'd in part, and remanded sub nom. AT\&T Corp. v. Iowa Utils. Bd., 525 U.S. 366 (1999). Bell Atlantic was required to sell network elements at those TELRIC prices by virtue of merger conditions in the Bell Atlantic/NYNEX merger proceedings. See Bell Atlantic/NYNEX Order, supra note 3, I 113. See also Reed Hundt, Chairman, Fed. Commc'ns Comm'n, Remarks to State Commissioners on the Bell Atlantic/NYNEX Merger (Oct. 3, 1997), available at http://www.fcc.gov/Speeches/Hundt/spreh758.html. One does not have to agree or disagree with TELRIC pricing of UNEs to recognize the ad hoc nature of this policy, as other Bell companies, such as BellSouth and U.S. WEST, were not subject to such rules.

84 In re Appropriate Framework for Broadband Access to the Internet over Wireline Facilities; Review of Regulatory Requirements for Incumbent LEC Broadband Telecommunications Services; Computer III Further Remand Proceedings: Bell Operating Company Provision of Enhanced Services; 1998 Biennial Regulatory Review-Review of Computer III and ONA Safeguards and Requirements; Inquiry Concerning High-Speed Access to the Internet Over Cable and Other Facilities; Internet Over Cable Declaratory Ruling; Appropriate Regulatory Treatment for Broadband Access to the Internet Over Cable Facilities, 
AT\&T and Verizon-MCI mergers. ${ }^{85}$ Yet, the nation's cable industry, which provides more residential broadband connections than AT\&T and Verizon combined, has not been subject to that same network neutrality regime, nor has Qwest, BellSouth, or the nation's other local telephone or wireless companies. ${ }^{86}$ The merits of such a policy should be debated and considered on an industry-wide basis in a forum of industry-wide applicability ${ }^{87}$ Only in that setting can the industry and the public actively participate in its construction, application, and uniform enforcement. ${ }^{88}$

The merger condition drafting and adoption process as a practical matter does not live up to this obligation, as it often occurs in negotiations between the FCC and the merging entities with very little opportunity for public input and review. Are consumers really well-served by backroom, closed-door negotiations between the regulator and prospective merging parties over important public issues? The opportunity for the regulator and the regulated to game such

Policy Statement, 20 F.C.C.R. 14,986, $\mid 4$ (Aug. 5, 2005).

85 In re SBC Communications Inc. and AT\&T Corp. Applications for Approval of Transfer of Control, Memorandum Opinion and Order, 20 F.C.C.R. 18,290, ๆ 3 (Oct. 31, 2005); In re Verizon Communications Inc. and MCI, Inc., Applications for Approval of Transfer of Control, Memorandum Opinion and Order, 20 F.C.C.R. 18,433, ๆ 3 (Oct. 31, 2005).

86 The FCC did sanction Comcast, in its role as an Internet Service Provider, for violating the Internet Policy Statement in 2008. In re Formal Complaint of Free Press and Public Knowledge Against Comcast Corporation for Secretly Degrading Peer-to-Peer Applications; Broadband Industry Practices, Petition of Free Press et al. for Declaratory Ruling that Degrading an Internet Application Violates the FCC's Internet Policy Statement and Does Not Meet an Exception for "Reasonable Network Management," Memorandum Opinion and Order, 23 F.C.C.R. 13,028 (Aug. 1, 2008). However, Comcast challenged that decision in the D.C. Circuit, which vacated the FCC's order in April 2010. See Comcast Corp. v. FCC, No. 08-1291, 2010 WL 1286658 at *1-2 (D.C. Cir. April 6, 2010). In late 2009, the FCC released proposed rules to codify its Internet Service Policy Statement. In re Preserving the Open Internet Broadband Industry Practices, Notice of Proposed Rulemaking, 24 F.C.C.R. 13,064 (Oct. 22, 2009).

87 Proponents of such a policy would no doubt prefer nationwide rules of general applicability but might view mergers as a "second-best" alternative. But this temptation should be avoided because it has the potential to create a complicated patchwork of legal regimes over which there is a clear, nationwide interest.

88 Using merger related proceedings to change existing regulations also could run afoul of the Administrative Procedure Act's ("APA") requirements that an agency provide adequate public notice of any pending rule change or decision. See Administrative Procedure Act $\S 1,5$ U.S.C. $\S 553$ (2006). The Supreme Court has held that if an agency adopts "a new position inconsistent with" an existing regulation or effects "a substantive change in the regulation," notice and comment under section 553(b) of the APA is required. See Shalala v. Guernsey Mem'l Hosp., 514 U.S. 87, 100 (1995). The D.C. Circuit recently noted that "fidelity to the rulemaking requirements of the APA bars courts from permitting agencies to avoid those requirements by calling a substantive regulatory change an interpretive rule." U.S. Telecomm. Ass'n v. FCC, 400 F.3d 29, 35 (D.C. Cir. 2005). 
a system to the exclusion of important consumer and competitor interests is strong.

In conclusion, while it is appropriate to impose narrowly-tailored conditions to remedy specific merger-related harms when consumer welfare is at risk, to the extent there are policy issues of generic concern, those issues are better handled in an agency proceeding where they can be effectively dealt with in a focused, comprehensive, and public manner. ${ }^{89}$

\section{CONCLUSION}

Without question, the FCC has the authority and obligation to review communications industry mergers. But this authority is constrained: precedent demands that the FCC establish and carry out a cohesive and rigorous approach to merger review that is supported by the law, economics and, of course, the facts. Merger conditions must take into account competitive factors but also must be in the "public interest" and not the interest of individual competitors that are looking to saddle their rivals with unique regulatory burdens.

While there are restraints on the FCC's merger authority, the public interest standard does give the agency great power. Such power begets temptationincluding the temptation to seek to accomplish through merger conditions policy outcomes that would otherwise be difficult to obtain. But FCC Commissioners should exercise restraint in their efforts to regulate through so-called "voluntary" merger commitments. Important public policy issues deserve to be debated openly in industry-wide settings and should not be hidden in the backrooms of the FCC.

89 The FCC has recognized this principle. See Adelphia Order, supra note 26, If 192 ("We find that some of the concerns raised are not transaction-specific and are more appropriately addressed in other proceedings."). 
